\title{
c-Fms-mediated differentiation and priming of monocyte lineage cells play a central role in autoimmune arthritis
}

\author{
Ricardo T Paniagua 1,2, Anna Chang ${ }^{1,2}$, Melissa M Mariano 1,2, Emily A Stein ${ }^{1,2}$, Qian Wang ${ }^{1,2}$, Tamsin M Lindstrom ${ }^{1,2}$,
} Orr Sharpe ${ }^{1,2}$, Claire Roscow ${ }^{1,2}$, Peggy P Ho ${ }^{3}$, David M Lee ${ }^{4}$, William H Robinson ${ }^{1,2^{*}}$

\begin{abstract}
Introduction: Tyrosine kinases are key mediators of multiple signaling pathways implicated in rheumatoid arthritis (RA). We previously demonstrated that imatinib mesylate-a Food and Drug Administration (FDA)-approved, antineoplastic drug that potently inhibits the tyrosine kinases Abl, c-Kit, platelet-derived growth factor receptor (PDGFR), and c-Fms-ameliorates murine autoimmune arthritis. However, which of the imatinib-targeted kinases is the principal culprit in disease pathogenesis remains unknown. Here we examine the role of c-Fms in autoimmune arthritis.
\end{abstract}

Methods: We tested the therapeutic efficacy of orally administered imatinib or GW2580, a small molecule that specifically inhibits C-Fms, in three mouse models of RA: collagen-induced arthritis (CIA), anti-collagen antibodyinduced arthritis (CAIA), and K/BxN serum transfer-induced arthritis (K/BxN). Efficacy was evaluated by visual scoring of arthritis severity, paw thickness measurements, and histological analysis. We assessed the in vivo effects of imatinib and GW2580 on macrophage infiltration of synovial joints in CIA, and their in vitro effects on macrophage and osteoclast differentiation, and on osteoclast-mediated bone resorption. Further, we determined the effects of imatinib and GW2580 on the ability of macrophage colony-stimulating factor (M-CSF; the ligand for c-Fms) to prime bone marrow-derived macrophages to produce tumor necrosis factor (TNF) upon subsequent Fc receptor ligation. Finally, we measured M-CSF levels in synovial fluid from patients with RA, osteoarthritis $(O A)$, or psoriatic arthritis (PsA), and levels of total and phosphorylated c-Fms in synovial tissue from patients with RA.

Results: GW2580 was as efficacious as imatinib in reducing arthritis severity in CIA, CAIA, and K/BxN models of RA. Specific inhibition of c-Fms abrogated (i) infiltration of macrophages into synovial joints of arthritic mice; (ii) differentiation of monocytes into macrophages and osteoclasts; (iii) osteoclast-mediated bone resorption; and (iv) priming of macrophages to produce TNF upon Fc receptor stimulation, an important trigger of synovitis in RA. Expression and activation of C-Fms in RA synovium were high, and levels of M-CSF were higher in RA synovial fluid than in OA or PsA synovial fluid.

Conclusions: These results suggest that c-Fms plays a central role in the pathogenesis of RA by mediating the differentiation and priming of monocyte lineage cells. Therapeutic targeting of c-Fms could provide benefit in RA.

\section{Introduction}

Rheumatoid arthritis (RA) is an autoimmune synovitis that affects $0.6 \%$ of the world population [1]. RA is characterized by inflammation and pannus formation in the

\footnotetext{
* Correspondence: wrobins@stanford.edu

'Department of Medicine, Division of Immunology and Rheumatology, Stanford University School of Medicine, CCSR 4135, 269 Campus Drive, Stanford, CA 94305, USA
}

synovial joints and by periarticular erosions, biomechanical dysfunction, and early mortality. Although the advent of biological therapeutics has revolutionized the treatment of RA, a significant number of patients with RA do not respond well to therapy. The current generation of biologic agents either blocks a critical cytokine, such as tumor necrosis factor (TNF) [2], or targets cells of the adaptive immune system, such as B [3] and T [4]

\section{Biomed Central}


cells. However, non-antigen-specific cellular responses may also contribute to the pathogenesis of RA [1]. While adaptive autoimmune responses directed against synovial joint antigens are likely involved in the early stages of RA, widespread dysregulation of non-antigenspecific cellular responses-including aggressive growth of fibroblast-like synoviocytes (FLSs), proinflammatory cytokine production by macrophages, and activation of osteoclasts-likely underlies the chronic inflammatory stage of RA. Elucidation of the cellular responses that are central to the pathogenesis of RA could lead to the development of novel targeted therapies.

Imatinib mesylate (imatinib) is a tyrosine kinase inhibitor approved for the treatment of Bcr-Abl-expressing chronic myelogenous leukemias and c-Kit-expressing gastrointestinal stromal tumors [5,6]. Recent case reports describe the alleviation of RA symptoms in RA patients receiving imatinib for the treatment of these cancers [7-9], suggesting that tyrosine kinases are important in the pathogenesis of RA. Indeed, we and others have shown that imatinib ameliorates autoimmune arthritis in animal models of RA [10-12]. At micromolar concentrations, imatinib inhibits a narrow spectrum of tyrosine kinases, including c-Kit, plateletderived growth factor receptor (PDGFR) $\alpha / \beta, \mathrm{Abl}$, Abl-related kinases, and c-Fms (also known as colonystimulating factor receptor 1) [13-15]. We previously demonstrated that micromolar concentrations of imatinib abrogated multiple pathways implicated in RA pathogenesis, including production of proinflammatory cytokines by synovial macrophages, proliferation of FLSs, production of TNF by mast cells, and proliferation of, and antibody production by, B cells [12]. These effects were associated with inhibition of c-Fms activation in synovial macrophages, of PDGFR activation in FLSs, and of c-Kit activation in mast cells. Still unknown are the relative contribution of these kinases and their associated cellular responses to the pathogenesis of RA. Elucidation of the kinases central to pathogenesis would enable the development of highly specific inhibitors with an improved therapeutic index for the treatment of RA.

Accumulating evidence underscores the importance of monocyte lineage cells in the chronic inflammatory stage of RA. Upon migration to tissues, monocytes differentiate into macrophages and osteoclasts, which perform several homeostatic functions $[16,17]$. In addition to their role in immune defense, macrophages clear cell debris and participate in tissue remodeling following an inflammatory response. Osteoclasts play a key role in bone remodeling by resorbing bone, and under physiological conditions, their activity is tightly coordinated with that of osteoblasts, which are responsible for forming bone [18]. In RA, monocyte lineage cells are aberrantly activated: an increase in macrophage infiltration of the synovium promotes inflammation via the production of TNF and other proinflammatory cytokines, and an increase in osteoclast activity promotes erosion of bone [19].

Development and proliferation of monocyte lineage cells are mediated by c-Fms [17], a member of the PDGFR family of tyrosine kinases. The c-Fms ligand macrophage colony-stimulating factor (M-CSF) is produced predominantly by FLSs, T cells, and endothelial cells, and its expression is upregulated in these cells in RA [20,21]. Recently, interleukin-34 (IL-34) was identified as a second ligand for c-Fms [22]. Although c-Fms has been implicated in RA, prior studies have not fully defined the cellular mechanisms by which c-Fms modulates autoimmune arthritis. Here, we dissect the role of c-Fms, demonstrating that c-Fms signaling promotes the formation and activation of macrophages and osteoclasts. These findings reveal the relevance of c-Fms to specific cellular processes important in the pathogenesis of RA. Furthermore, we demonstrate that a specific small-molecule inhibitor of c-Fms is effective in treating arthritis in multiple mouse models of RA.

\section{Materials and methods}

\section{Small-molecule inhibitors and antibodies}

In the in vitro studies, we used imatinib mesylate that was chemically synthesized and confirmed to be more than $98 \%$ pure by the Organic Synthesis Core Facility at Memorial Sloan-Kettering Cancer Center (New York, NY, USA). In the in vivo studies, we used imatinib mesylate tablets (Stanford Inpatient Pharmacy Services, Palo Alto, CA, USA), which were ground and resuspended in the vehicle. GW2580 provided by GlaxoSmithKline (Uxbridge, Middlesex, UK) was used in the studies on prevention of arthritis (Figures 1 and 2). GW2580 purchased from Calbiochem (San Diego, CA, USA) and GW2580 chemically synthesized and confirmed to be more than $99 \%$ pure by SRI International (Menlo Park, CA, USA) were used in the studies on the treatment of arthritis (Figures 1 and 2), the experiments shown in Figures 3, 4, 5 and 6, and the experiments shown in Additional file 1. Anti-c-Fms, anti-phospho-cFms, and isotype control antibodies were from Santa Cruz Biotechnology, Inc. (Santa Cruz, CA, USA).

\section{$\mathrm{IC}_{50}$ determination}

c-Kit and Abl kinase activity in the presence or absence of small-molecule inhibitors was determined by using HTScan kinase assay kits (Cell Signaling Technology, Inc., Danvers, MA, USA) coupled with europiumlabeled DELFIA assays (PerkinElmer, Waltham, MA, USA), and counts were measured by time-resolved fluorescence (PerkinElmer) in accordance with the protocols of the manufacturer. To assess c-Fms activity, we 


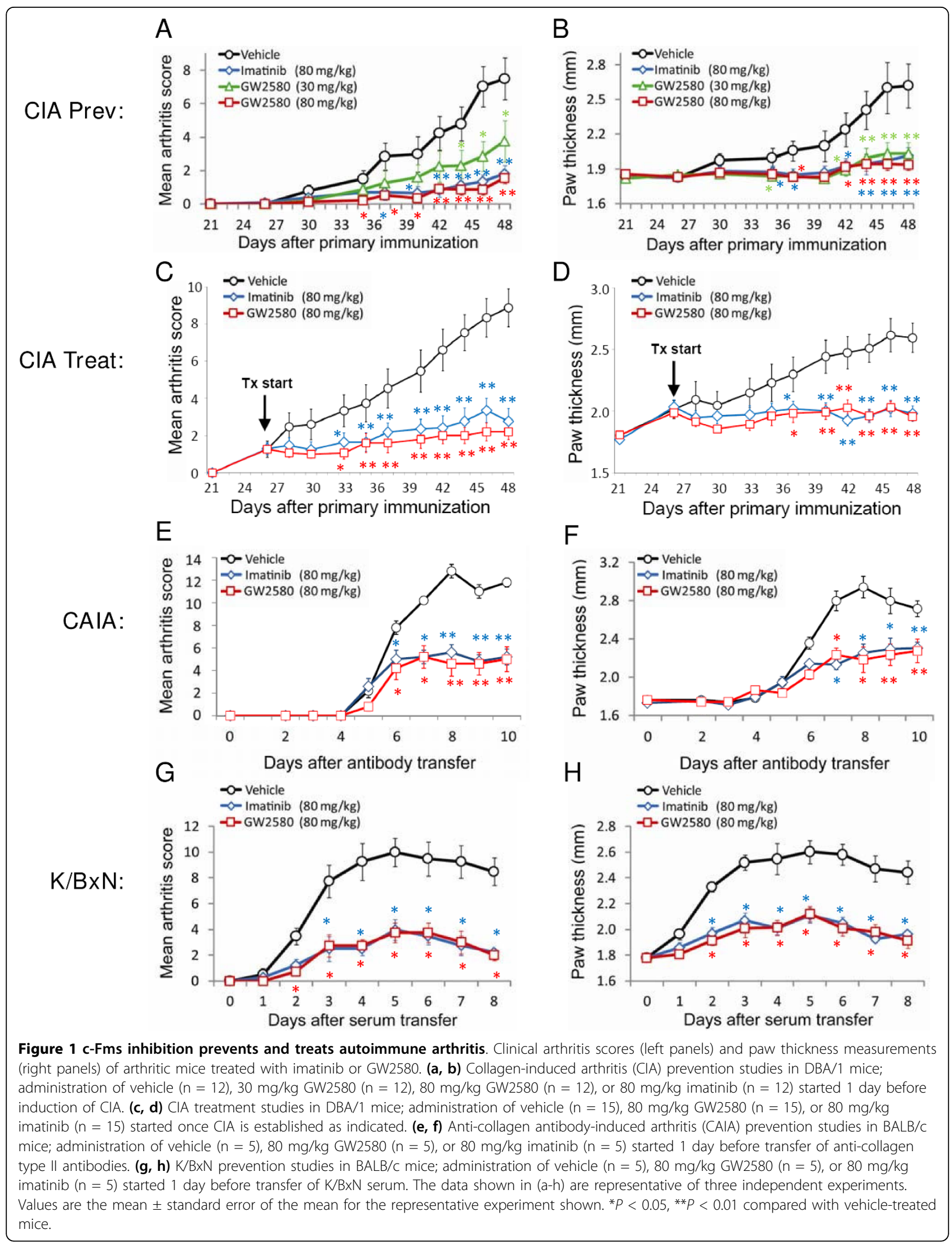




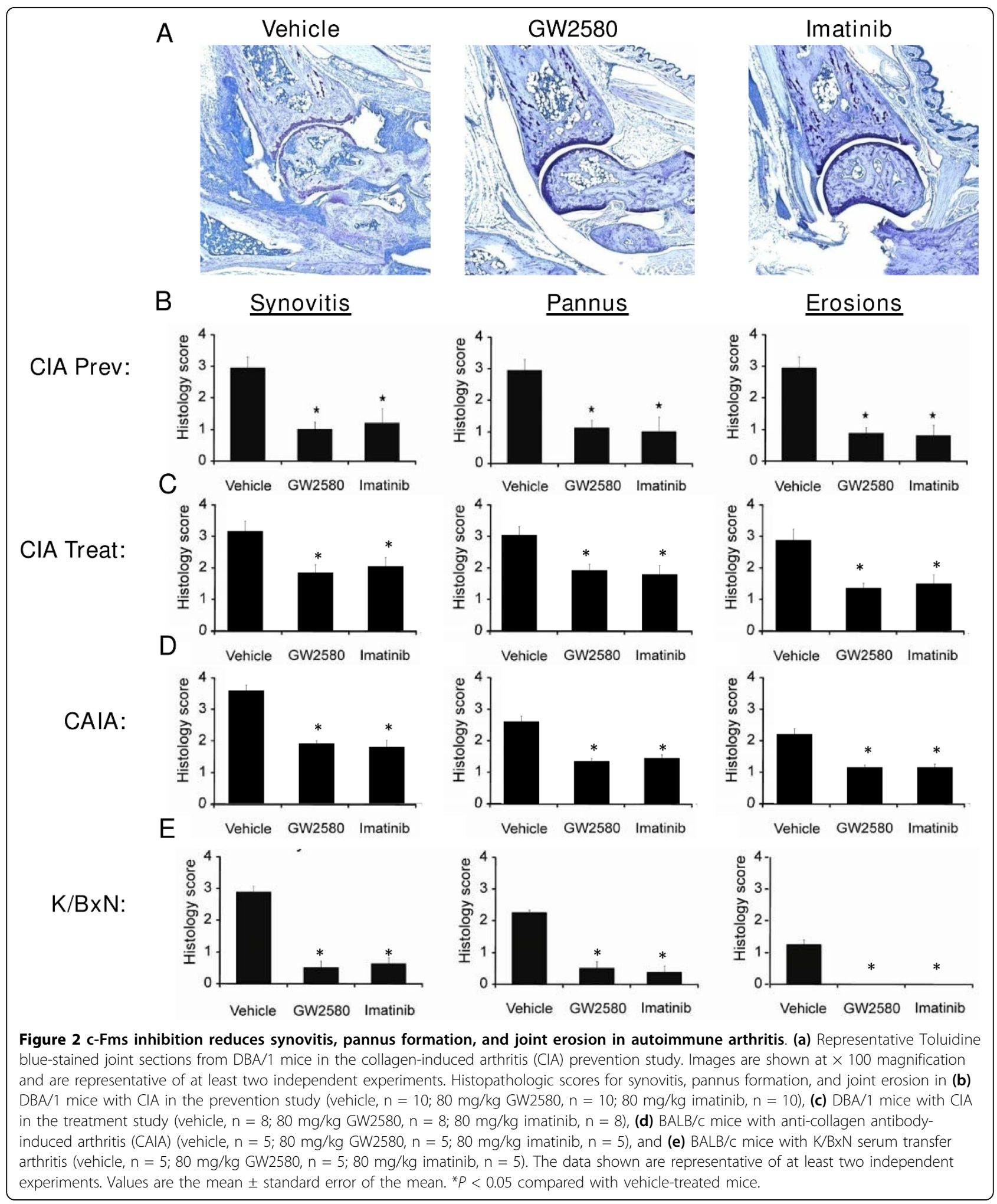




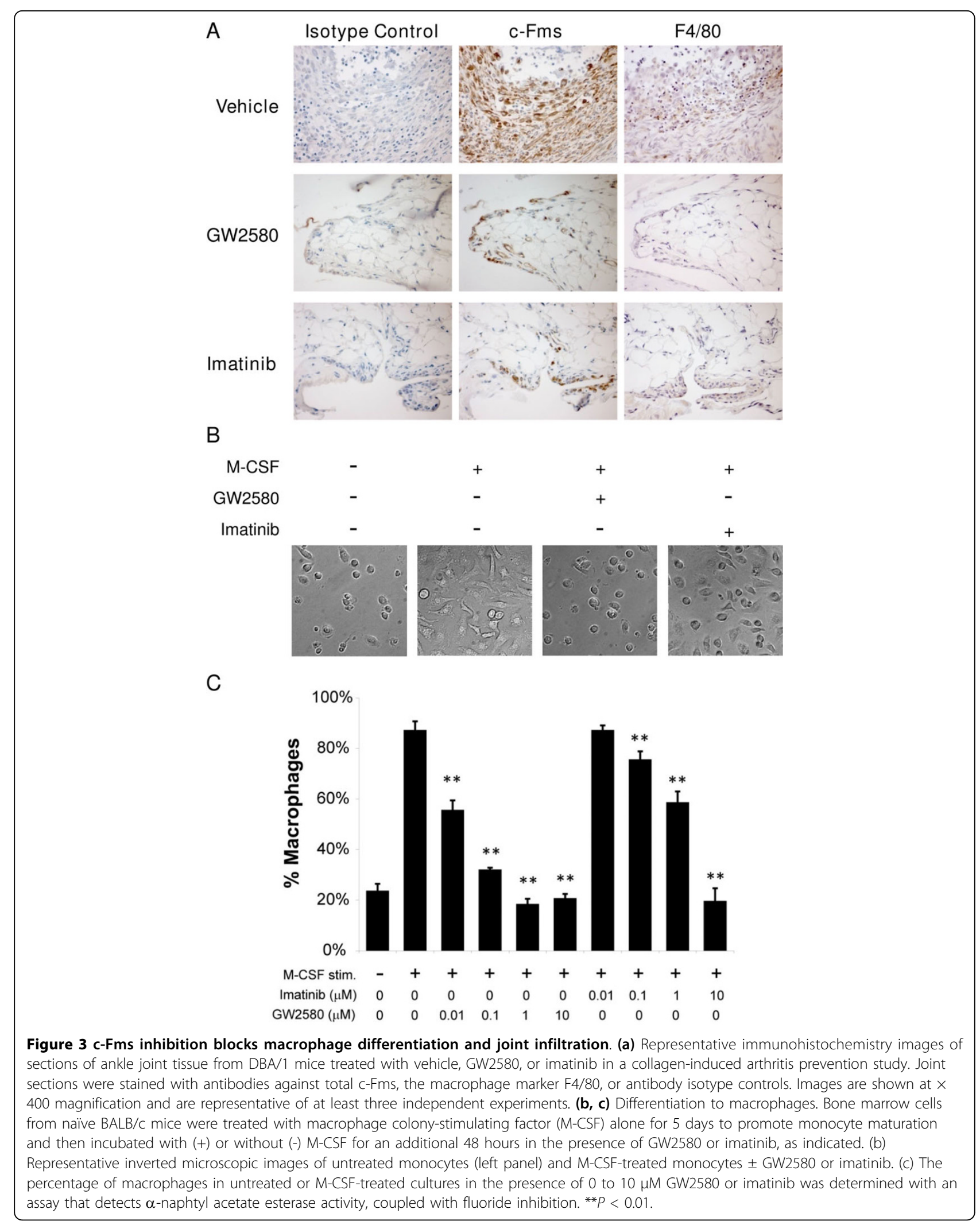




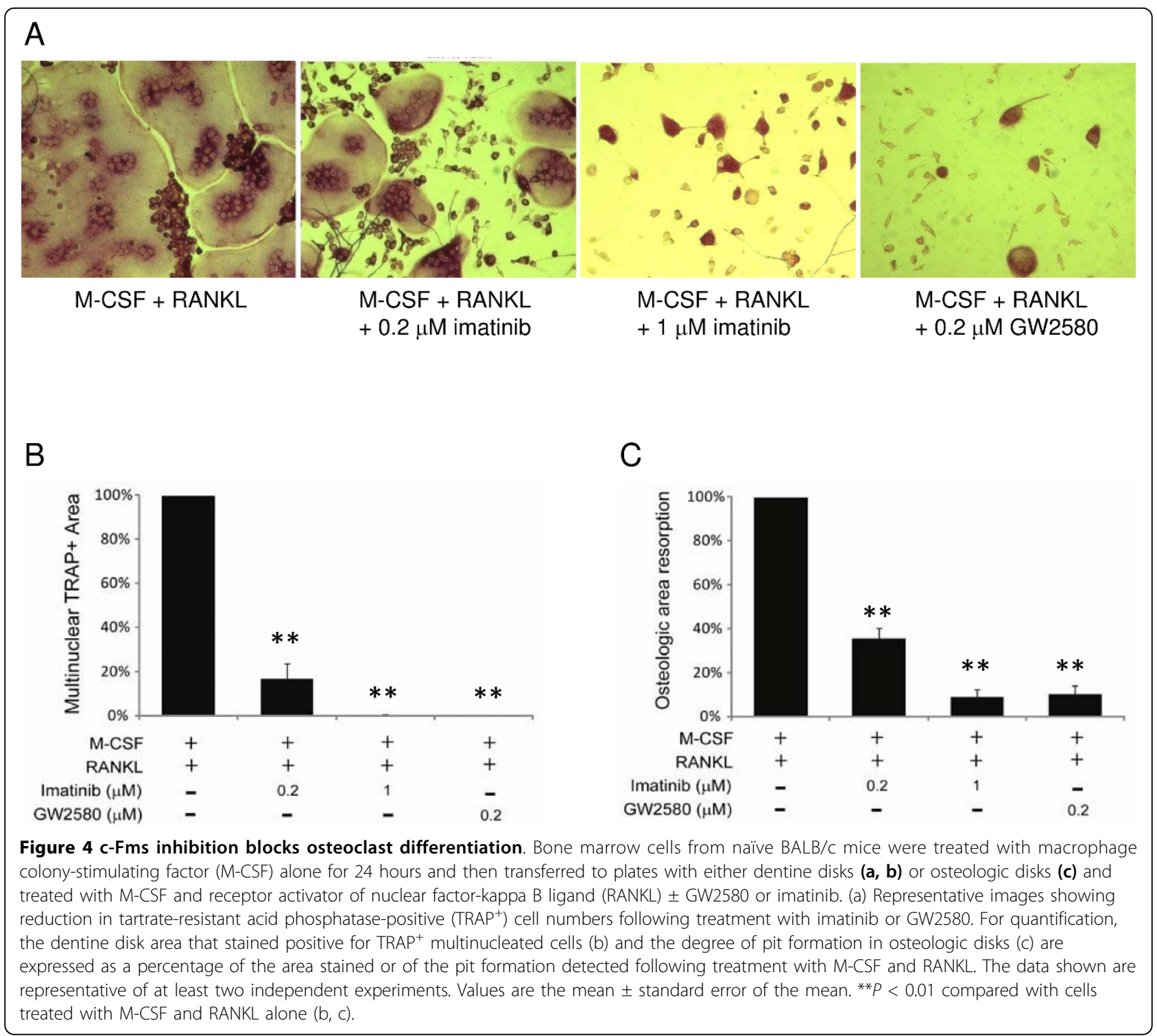

incubated human peripheral blood mononuclear cells with $20 \mathrm{ng} / \mathrm{mL} \mathrm{M-CSF}$ in the presence or absence of small-molecule inhibitors and determined the percentage of macrophages, as described below. To assess PDGFR activity, we isolated human FLSs as previously described [12], stimulated them for 72 hours with 20 $\mathrm{ng} / \mathrm{mL}$ PDGF-bb in the presence of small-molecule inhibitors, pulsed them with $1 \mu \mathrm{Ci}\left[{ }^{3} \mathrm{H}\right]$ thymidine (ICN Pharmaceuticals, Costa Mesa, CA, USA) for the final 18 hours of the stimulation, and used a Betaplate scintillation counter (PerkinElmer) to quantify the radioactivity incorporated. Scintillation counts were used to generate nonlinear regression dose-response curves for each small-molecule inhibitor, and $\mathrm{IC}_{50} \mathrm{~s}$ (half inhibitory concentrations) were determined by using Prism software (GraphPad Software, Inc., San Diego, CA, USA).

\section{Synovial fluid and tissue samples from patients with arthritis}

Human synovial fluid and synovial tissue samples were collected from RA, osteoarthritis (OA), and psoriatic arthritis (PsA) patients who met the American College of Rheumatology criteria. Samples were collected in accordance with protocols approved by the Stanford University Institutional Review Board after procurement of informed consent.

\section{Models of autoimmune arthritis}

Six- to eight-week-old male DBA/1 mice and female BALB/c mice were purchased from The Jackson Laboratory (Bar Harbor, ME, USA) and housed at Stanford University under protocols approved by the Stanford University Committee of Animal Research and in 


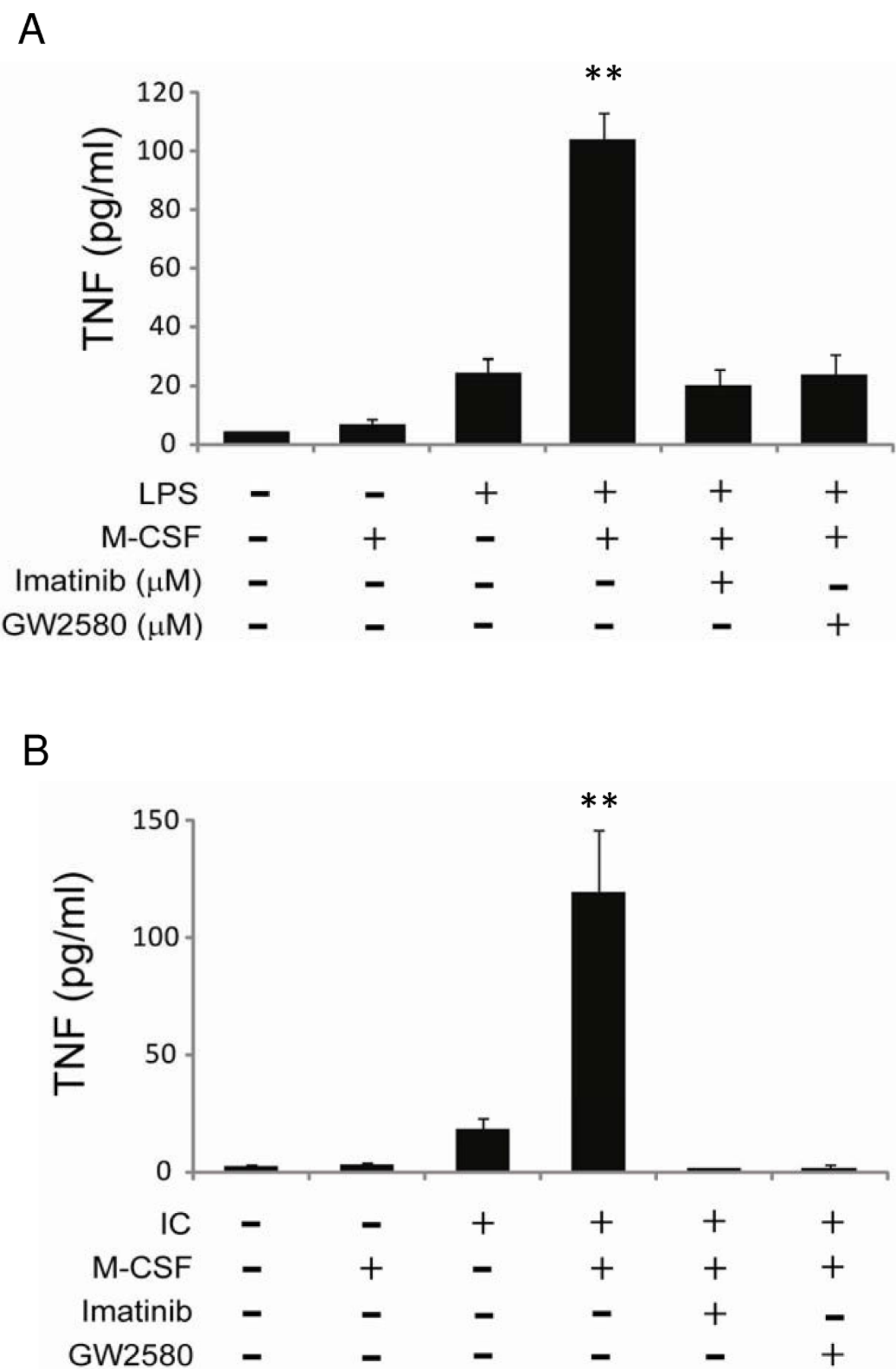

Figure 5 c-Fms signaling primes macrophage response to lipopolysaccharide (LPS) or immune complex stimulation. Fully differentiated bone marrow-derived macrophages pretreated with macrophage colony-stimulating factor (M-CSF) for 3 hours in the absence or presence of 5

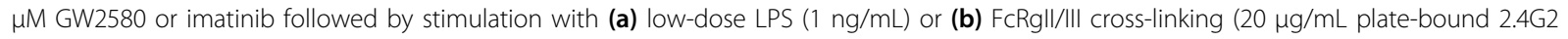
antibody). After 24 hours of culture, tumor necrosis factor (TNF) in the supernatants was measured by enzyme-linked immunosorbent assay. Values are the mean \pm standard error of the mean. ${ }^{* *} p<0.01$ compared with unprimed stimulated cells without inhibitor. Results are representative of at least three independent experiments. IC, immune complex. 
A

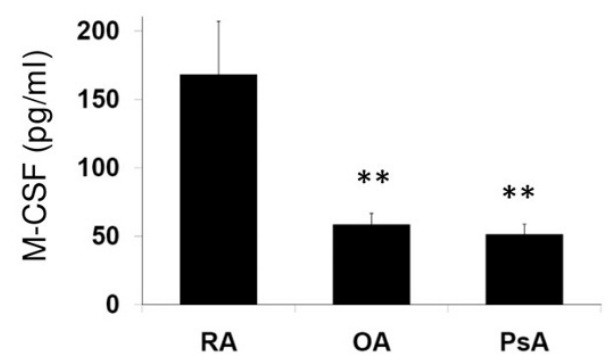

B

Isotype Control

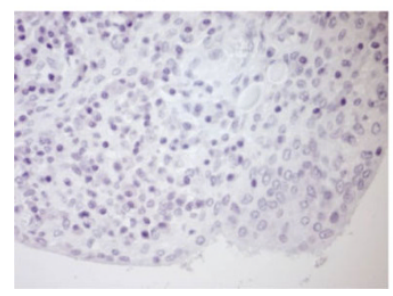

Total c-Fms

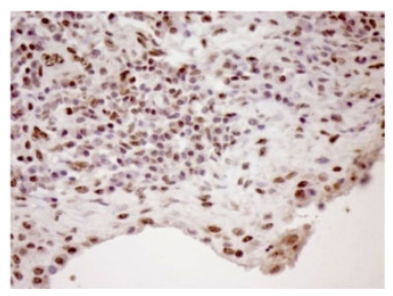

Phospho-c-Fms

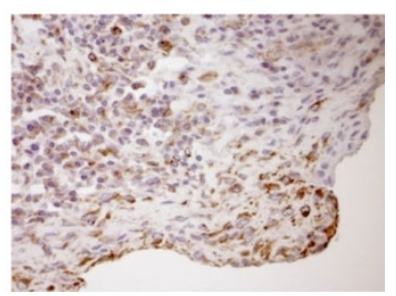

Figure 6 Macrophage colony-stimulating factor (M-CSF), total c-Fms, and phospho-c-Fms are upregulated in human rheumatoid arthritis (RA) synovium. (a) Levels of M-CSF in synovial fluid from patients with RA ( $n=14)$, osteoarthritis (OA) $(n=15)$, or psoriatic arthritis (PsA) $(n=12)$ were measured by Luminex bead-based arrays. Values are the mean \pm standard error of the mean. ${ }^{* *} P<0.01$ compared with RA samples. (b) Representative immunohistochemical images of RA synovium stained with antibodies against c-Fms, phospho-c-Fms, or isotype controls.

accordance with National Institutes of Health guidelines. Collagen-induced arthritis (CIA) in DBA/1 mice was induced and scored as previously described [23]. Briefly, DBA/1 mice were immunized by intradermal injection of $100 \mu \mathrm{g} /$ mouse bovine collagen type II (CII) (Chondrex, Inc., Redmond, WA, USA) emulsified in complete Freund's adjuvant (CFA) containing $250 \mu \mathrm{g} /$ mouse heat-killed Mycobacterium tuberculosis $\mathrm{H} 37 \mathrm{Ra}$ (Becton, Dickinson and Company, Franklin Lakes, NJ, USA). Twenty-one days after immunization, mice were given a subcutaneous boost injection (at the base of the tail) of $100 \mu \mathrm{g} /$ mouse bovine CII emulsified in incomplete Freund's adjuvant (IFA). In BALB/c mice, anti-collagen antibody-induced arthritis (CAIA) was induced by intravenous injection of $1 \mathrm{mg}$ of Arthrogen monoclonal antibody blend (Chondrex, Inc.) followed by $25 \mu \mathrm{g}$ of lipopolysaccharide (LPS) (Chondrex, Inc.) 3 days later. $\mathrm{K} / \mathrm{BxN}$ arthritis was induced in $\mathrm{BALB} / \mathrm{c}$ mice by intraperitoneal (i.p.) injection of $1 \mu \mathrm{L}$ of $\mathrm{K} / \mathrm{BxN}$ serum per 1 $\mathrm{g}$ of mouse weight, followed 48 hours later by i.p. injection of $0.5 \mu \mathrm{L}$ of $\mathrm{K} / \mathrm{BxN}$ serum per $1 \mathrm{~g}$ of mouse weight. Arthritis severity was evaluated according to the following visual scoring system: $0=$ no swelling or erythema; 1 = mild swelling and erythema of digits or paw; 2 = moderate swelling and erythema confined to the area distal to the mid-paw; $3=$ more-pronounced swelling and erythema extending to the ankle; $4=$ severe swelling, erythema, and joint rigidity of the ankle, foot, and digits. Each limb was assigned a score of 0 to 4 , with a maximum possible score of 16 for each mouse. Paw thickness was determined by measuring the thickness of both hind paws with 0 - to 10 -mm calipers and calculating the mean of the two measurements.

\section{In vivo dosing with small-molecule inhibitors}

For administration in vivo, GW2580 and imatinib were diluted in $0.5 \%$ hydroxypropylmethylcellulose and $0.05 \%$ Tween-80 solution. GW2580 and imatinib were delivered by oral gavage twice daily at the specified doses, starting 1 day before immunization in the CIA prevention studies, following arthritis development (average visual arthritis score of 2) in the CIA treatment studies, and 1 day before antibody transfer in the CAIA or K/ $\mathrm{BxN}$ arthritis studies. Dosing was continued for the duration of the experiment. Administration of vehicle had no effect on the onset or severity of arthritis in mice.

\section{Histological evaluation}

Hind limbs from mice with autoimmune arthritis were fixed and decalcified in CalEx II (Fischer Scientific, Pittsburgh, PA, USA) for 3 days before being paraffin- 
embedded. Histological assessment of arthritis severity was made by blinded evaluation of Toluidine bluestained joint sections in accordance with a previously described scoring system: $0=$ normal; $1=$ mild inflammation, mild hyperplasia of the synovial lining layer, and mild cartilage destruction without bone erosion; 2 to 4 = increasing degrees of inflammatory cell infiltrates, synovial lining hyperplasia and pannus formation, and cartilage and bone destruction [24].

\section{Immunohistochemistry}

Sections of paraffin-embedded synovium from RA patients and decalcified joint tissue from mice with autoimmune arthritis were deparaffinized, rehydrated, and subjected to antigen retrieval as described previously $[25,26]$.

\section{Macrophage differentiation}

Bone marrow cells were harvested from BALB/c mice and monocyte lineage cells were generated according to standard procedures [27]. After 4 to 5 days of culture, bone marrow-derived monocytes were incubated for 48 hours with $20 \mathrm{ng} / \mathrm{mL}$ M-CSF (PeproTech, Rocky Hill, NJ, USA) in the presence of 0 to $10 \mu \mathrm{M}$ GW2580 or imatinib. To distinguish between monocytes and macrophages, we performed an $\alpha$-napthyl acetate esterase assay, coupled with fluoride inhibition, in accordance with the protocol of the manufacturer (SigmaAldrich). At least 100 monocytes and macrophages were counted in triplicate for each experimental condition, and data are expressed as a percentage of macrophages in culture.

\section{Osteoclast differentiation}

Twenty-four hours after their isolation from BALB/c mice, undifferentiated bone marrow cells were transferred to dentine disks (Immunodiagnostic Systems, Scottsdale, AZ, USA) or osteologic disks (BD Biosciences, San Jose, CA, USA) and cultured for 6 days in the presence of $50 \mathrm{ng} / \mathrm{mL} \mathrm{M}-\mathrm{CSF}$ and $50 \mathrm{ng} / \mathrm{mL}$ receptor activator of nuclear factor-kappa-B ligand (RANKL) (PeproTech) together with 0 to $5 \mu \mathrm{M}$ small-molecule inhibitor. To identify multinucleated, tartrate-resistant acid phosphatase-positive $\left(\mathrm{TRAP}^{+}\right)$osteoclasts, we stained cells cultured on dentine disks with the acid phosphatase leukocyte kit (Sigma-Aldrich). ImageJ software was used to determine the dentine disk area that stained positive for $\mathrm{TRAP}^{+}$multinucleated cells. Pit formation was assessed by measuring the removal of surface film on osteologic disks with the Bioquant Osteo II image quantification system (Bioquant Image Analysis Corporation, Nashville, TN, USA).

\section{Macrophage priming}

Bone marrow cells were harvested from BALB/c mice and macrophages were generated as previously described [27]. Macrophages were cultured overnight in complete RPMI media in the absence of M-CSF and then incubated for 3 hours in the presence of 0 to $50 \mathrm{ng} / \mathrm{mL} \mathrm{M}-\mathrm{CSF}$ and 0 to $5 \mu \mathrm{M}$ small-molecule inhibitor, as described above. After 3 hours, cells were stimulated with $1 \mathrm{ng} / \mathrm{mL}$ LPS (Sigma-Aldrich) or $20 \mu \mathrm{g} / \mathrm{mL}$ plate-bound rat anti-mouse 2.4G2 (BD Biosciences) for 24 hours, as previously described [28], and supernatants were harvested for cytokine analysis by enzyme-linked immunosorbent assay (ELISA).

\section{T-cell stimulation}

Splenocytes from CIA mice treated chronically with 80 $\mathrm{mg} / \mathrm{mL}$ GW2580, $80 \mathrm{mg} / \mathrm{mL}$ imatinib, or vehicle were stimulated for 72 hours with $20 \mu \mathrm{g} / \mathrm{mL}$ whole, denatured bovine CII (Chondrex, Inc.). One microcurie of $\left[{ }^{3} \mathrm{H}\right]$ thymidine (ICN Pharmaceuticals) was added for the final 18 hours of culture, and radioactivity incorporation was quantified by using a Betaplate scintillation counter. Supernatants after 72 hours were harvested for cytokine analysis by ELISA.

\section{Statistics}

Visual arthritis scores, paw thicknesses, and histology scores were compared by the Mann-Whitney $U$ test with GraphPad InStat Version 3.0 (GraphPad Software, Inc.). Differences in arthritis scores were determined by the Fisher test with Analyse-it plug-in software (Analyse-it Software, Ltd., Leeds, UK) for Excel (Microsoft Corporation, Redmond, WA, USA). Macrophage differentiation, osteoclast differentiation, macrophage priming, and cytokine level were compared by unpaired $t$ tests with GraphPad InStat Version 3.0 (GraphPad Software, Inc.).

\section{Results}

c-Fms inhibition prevents and treats autoimmune arthritis To determine whether specific inhibition of c-Fms provides benefit in autoimmune arthritis, we explored the effects of GW2580 in several distinct models of RA and compared them with the effects of imatinib. Imatinib inhibits c-Kit, Abl, PDGFR, and c-Fms with $\mathrm{IC}_{50} \mathrm{~s}$ of 0.1 , $0.25,0.1$, and $1.4 \mu \mathrm{M}$, respectively. On the basis of published pharmacokinetic profiles [12], imatinib was administered to mice orally, twice daily at a dose of $80 \mathrm{mg} / \mathrm{kg}$. GW2580 was administered to mice orally, twice daily at doses of 30 or $80 \mathrm{mg} / \mathrm{kg}$. Previous pharmacokinetic studies in mice have determined that oral administration of $80 \mathrm{mg} / \mathrm{kg} \mathrm{GW} 2580$ yields a maximal plasma concentration of $5.6 \mu \mathrm{M}$ [29]. To determine the $\mathrm{IC}_{50}$ of GW2580 for the kinases c-Kit and Abl, we used cell-free kinase 
assays with time-resolved fluorescence. The $\mathrm{IC}_{50} \mathrm{~s}$ were $73.5 \mu \mathrm{M}$ for $\mathrm{Abl}$ (Additional file 1a) and greater than $100 \mu \mathrm{M}$ for c-Kit (Additional file 1b) and concentrations significantly above the maximal plasma concentrations of GW2580 achieved in mice receiving $80 \mathrm{mg} / \mathrm{kg} \mathrm{GW} 2580$. Using cell-based assays, we showed that GW2580 potently inhibits c-Fms $\left(\mathrm{IC}_{50}=0.01 \mu \mathrm{M}\right.$; Additional file 1c) and can inhibit PDGFR only at supraphysiological concentrations $\left(\mathrm{IC}_{50}=12.1 \mu \mathrm{M}\right.$; Additional file $1 \mathrm{~d}$ ). Thus, dosing of mice with GW2580 at a concentration of $80 \mathrm{mg} / \mathrm{kg}$ or less should inhibit c-Fms but not Abl, c-Kit, or PDGFR. Indeed, in a cell-free assay that measures the specificity of small-molecule inhibitors, GW2580 at 10 $\mu \mathrm{M}$ abolished c-Fms activity and did not cross-react with nearly 200 other kinases [30].

CIA was induced by injection of DBA/1 mice with bovine CII emulsified in CFA, followed 21 days later by a boost injection of CII emulsified in IFA. When imatinib dosing was initiated 1 day before the induction of CIA, it significantly reduced the severity of arthritis (Figure 1a, b), in agreement with our previous findings [12]. Likewise, mean arthritis scores and paw thickness measurements were significantly lower in mice dosed prophylactically with 30 or $80 \mathrm{mg} / \mathrm{kg}$ GW2580 compared with mice dosed with vehicle. GW2580 was as efficacious as imatinib in preventing the development of arthritis. Furthermore, when the kinase inhibitors were administered after the induction of arthritis, both GW2580 and imatinib significantly inhibited the progression of arthritis (Figure 1c, d). Mice were sacrificed between days 48 and 50 as this represents the peak of synovitis and inflammation. In the CIA experiments presented, all mice developed arthritis by the time the experiment was terminated (100\% incidence).

Imatinib has been shown to ameliorate CAIA [10]. We performed experiments to determine whether specific inhibition of c-Fms would yield a similar benefit in CAIA. We induced CAIA by injecting BALB/c mice with $1 \mathrm{mg}$ of anti-collagen antibodies, followed by $25 \mu \mathrm{g}$ of LPS 3 days later. Administration of GW2580 or imatinib was started 1 day before the transfer of antibodies. All CAIA mice developed arthritis by day 6 after antibody transfer (100\% incidence). Arthritis was significantly less severe in CAIA mice treated with the c-Fms-specific inhibitor GW2580 compared with vehicle-treated CAIA mice (Figure 1e, f). The course of arthritis in GW2580-treated CAIA mice mirrored that in imatinib-treated CAIA mice.

We induced $\mathrm{K} / \mathrm{BxN}$ arthritis in $\mathrm{BALB} / \mathrm{c}$ mice by transferring $1 \mu \mathrm{L}$ of serum/g of mouse weight, followed by $0.5 \mu \mathrm{L}$ of serum/g of mouse weight 48 hours later. Administration of GW2580 or imatinib was initiated 1 day before the transfer of serum. All $\mathrm{K} / \mathrm{BxN}$ mice developed arthritis by day 4 after serum transfer $(100 \%$ incidence). Arthritis was significantly less severe in K/ BxN mice treated with GW2580 or imatinib compared with vehicle-treated $\mathrm{K} / \mathrm{BxN}$ mice (Figure $1 \mathrm{~g}$, $\mathrm{h}$ ).

\section{c-Fms inhibition reduces histopathologic severity in autoimmune arthritis}

Histological analysis was performed on hind paws harvested from mice treated with $80 \mathrm{mg} / \mathrm{kg}$ GW 2580 , $80 \mathrm{mg} / \mathrm{kg}$ imatinib, or vehicle in the studies described above. Representative images of Toluidine blue-stained joint tissue sections from GW2580-, imatinib-, and vehicle-treated mice in the CIA prevention studies are presented (Figure 2a). Histopathologic evaluation by an investigator blinded to treatment groups for synovitis, formation of pannus, and erosion of cartilage and bone in paws derived from mice in CIA prevention (Figure $2 \mathrm{~b}, \mathrm{n}=10$ mice per group, with both hind paws from each mouse scored), CIA treatment (Figure 2c, $\mathrm{n}=8$ mice per group, with both hind paws from each mouse scored), CAIA (Figure $2 \mathrm{~d}, \mathrm{n}=5$ mice per group, with both hind paws for each mouse scored), and $\mathrm{K} / \mathrm{BxN}$ (Figure 2e, $\mathrm{n}=5$ mice per group, with both hind paws of each mouse scored) studies. In contrast, these histological indices of arthritis were significantly reduced in paws from GW2580- or imatinib-treated mice in all four models of autoimmune arthritis.

c-Fms inhibition does not modulate T-cell function in vivo Because imatinib has been shown to modulate T-cell function, we investigated whether specific inhibition of c-Fms with GW2580 affects T-cell function. Splenocytes harvested from CIA mice treated with $80 \mathrm{mg} / \mathrm{kg}$ GW2580, $80 \mathrm{mg} / \mathrm{kg}$ imatinib, or vehicle in the prevention studies were stimulated ex vivo with heat-denatured whole CII, and $\left[{ }^{3} \mathrm{H}\right]$ thymidine incorporation was used as a surrogate marker of T-cell proliferation. Cells harvested from vehicle- and GW2580-treated CIA mice proliferated extensively in response to CII, whereas cells harvested from imatinib-treated CIA mice exhibited a significantly reduced response (Additional file 2). In addition, splenocytes derived from imatinib-treated CIA mice stimulated with CII demonstrated significantly reduced production of the proinflammatory cytokines TNF and interferon-gamma compared with splenocytes derived from vehicle- or GW2580-treated CIA mice. There were no differences in IL-10 production in these same cell populations stimulated with CII. Thus, imatinib modulates $\mathrm{T}$-cell function in vivo, whereas GW2580 does not.

\section{c-Fms inhibition blocks differentiation of monocyte cells into macrophages}

To determine the effects of imatinib and GW2580 on macrophage infiltration of mouse joints, we assessed 
levels of total c-Fms and the macrophage-specific marker F4/80 in joint sections derived from CIA mice used in the prevention studies. We found that joints from CIA mice treated with vehicle exhibited marked expression of c-Fms protein, which colocalized with macrophages (Figure 3a). In contrast, in joints from CIA mice treated with $80 \mathrm{mg} / \mathrm{kg} \mathrm{GW} 2580$ or $80 \mathrm{mg} / \mathrm{kg}$ imatinib, both c-Fms protein expression and macrophage infiltration were reduced.

To determine whether c-Fms inhibition affects the formation of macrophages, we isolated bone marrow cells from naïve $\mathrm{BALB} / \mathrm{c}$ mice, treated them with M-CSF for 5 days to promote the maturation of monocytes, and cultured them for an additional 48 hours with M-CSF to promote their differentiation into macrophages, in the presence or absence of small-molecule inhibitors. Monocytes treated with M-CSF alone displayed a characteristic macrophage phenotype, including extension of multipolar processes and presence of heterogeneous cytoplasmic vacuoles and inclusion bodies (Figure $3 \mathrm{~b}$ ). In contrast, monocytes incubated with media alone and M-CSF-stimulated monocytes treated with $1 \mu \mathrm{M}$ GW2580 morphologically resembled undifferentiated monocytes. Treatment of monocytes with $\mathrm{M}-\mathrm{CSF}$ and $1 \mu \mathrm{M}$ imatinib resulted in a heterogeneous mix of cells, of which some morphologically resembled monocytes and others resembled macrophages.

To confirm the effects of the c-Fms inhibitors on macrophage formation, we applied an assay for the detection of $\alpha$-naphthyl acetate esterase activity, coupled with fluoride inhibition, to the cell culture system described above. In this assay, the granules of differentiated macrophages stain, whereas monocytes remain unstained [31]. Monocytes were generated as described above, cultured for 48 hours with M-CSF in the presence of 0 to $10 \mu \mathrm{M}$ GW2580 or imatinib, and then fixed and stained for $\alpha$-naphthyl acetate esterase activity. Approximately $20 \%$ of monocytes cultured in media alone formed macrophages; the addition of M-CSF increased the percentage of macrophages to nearly $90 \%$ of the total cell population (Figure 3c). Imatinib reduced macrophage formation in a dose-dependent manner. GW2580 suppressed macrophage formation at lower concentrations than imatinib, in keeping with GW2580 being the more potent c-Fms inhibitor. There were no differences in apoptosis between untreated cells and cells treated with imatinib or GW2580 (data not shown).

\section{c-Fms inhibition blocks the differentiation of monocytes into osteoclasts}

We performed experiments to determine whether GW2580 could suppress the formation of osteoclasts. Bone marrow cells were isolated from naïve BALB/c mice, and after 24 hours in culture with M-CSF, the suspension cells were transferred to plates containing dentine or osteologic discs and were co-cultured with M-CSF and RANKL in the presence or absence of GW2580 or imatinib. Treatment with M-CSF and RANKL led to marked formation of large TRAP $^{+}$multinucleated cells, which are indicative of osteoclasts. For each treatment condition, the dentine disk area that stained positive for $\mathrm{TRAP}^{+}$multinucleated cells was calculated by ImageJ software and expressed as a percentage of the area stained positive for $\mathrm{TRAP}^{+}$following treatment with M-CSF and RANKL alone. Both GW2580 and imatinib significantly reduced the formation of multinucleated TRAP ${ }^{+}$osteoclasts, albeit with different potencies (inhibition achieved with $0.2 \mu \mathrm{M}$ GW2580 was comparable to that achieved with $1 \mu \mathrm{M}$ imatinib) (Figure 4a, b). Because osteoclasts erode bone in RA joints, we next examined the formation of pits in osteologic disks, an indication of the ability of osteoclasts to resorb bone. We found that treatment of cells with imatinib $(0.2$ or $1 \mu \mathrm{M})$ resulted in a dose-dependent reduction in pit formation and that treatment with $0.2 \mu \mathrm{M}$ GW2580 blocked pit formation (Figure 4c).

\section{c-Fms activation primes macrophage tumor necrosis factor production in response to lipopolysaccharide or immune complex stimulation}

Whether c-Fms activation promotes anti-inflammatory or proinflammatory activity in fully differentiated macrophages is controversial [32,33]. To explore the role of $\mathrm{c}-\mathrm{Fms}$ in macrophage production of the proinflammatory cytokine TNF, we performed priming studies with fully differentiated macrophages derived from bone marrow cells of BALB/c mice. Macrophages primed with M-CSF for 3 hours in the presence or absence of $5 \mu \mathrm{M}$ GW2580 or imatinib were stimulated with $1 \mathrm{ng} / \mathrm{mL}$ LPS for 24 hours, and TNF protein in the cell culture supernatants was then measured by ELISA. Cells cultured in media alone or M-CSF alone produced very little TNF (Figure 5a). Low-dose LPS stimulated TNF production, which was significantly increased in macrophages primed with M-CSF for 3 hours before the addition of LPS. GW2580 or imatinib at $5 \mu \mathrm{M}$ (a clinically relevant concentration) reduced TNF production to levels detected in cells treated with LPS alone.

Although LPS is routinely used in experimental settings for the stimulation of proinflammatory cytokine production by macrophages, it is not a true trigger for the production of TNF in RA. Important physiological triggers of inflammation in RA are immune complexes that bind and activate Fc receptors [34]. To examine the role of cFms in TNF production elicited by immune complexes, we used the FcR-specific antibody 2.4G2 as a surrogate for immune complex-mediated Fc activation. Stimulation of macrophages with $2.4 \mathrm{G} 2$ alone for 24 hours elicited a 
small increase in TNF production (Figure 5b). Macrophages that were first primed with M-CSF for 3 hours and then stimulated with 2.4G2 produced substantial amounts of TNF. Co-culturing of cells with $5 \mu \mathrm{M}$ GW2580 or imatinib blocked the M-CSF- and 2.4G2induced increase in TNF production.

\section{Levels of total c-Fms, phospho-Fms, and M-CSF in rheumatoid arthritis patients}

To demonstrate involvement of the M-CSF/c-Fms axis in human RA, we used Luminex bead arrays to determine M-CSF protein levels in synovial fluid derived from patients with RA, OA, or PsA. M-CSF levels were significantly higher in human RA synovial fluid than in OA or PsA synovial fluid (Figure 6a). We also assessed levels of total c-Fms and phosphorylated c-Fms in human RA synovium and found that both expression and activation of c-Fms are high (Figure 6b).

\section{Discussion}

Imatinib studies to date have suggested that c-Fms, PDGFR, c-Kit, and/or Abl tyrosine kinase pathways may contribute to the pathogenesis of RA, but the dominant pathways and cellular mechanisms involved remain unclear [10-12]. Prior studies have not addressed the specific cellular mechanisms by which c-Fms mediates autoimmune arthritis. The studies provided herein suggest that c-Fms-mediated differentiation and activation of macrophages and osteoclasts play a central role in the pathogenesis of autoimmune arthritis. Furthermore, the c-Fms-specific inhibitor GW2580 was as efficacious as imatinib in the treatment of autoimmune arthritis.

In an adjuvant arthritis model in rats, GW2580 suppressed bone destruction but did not affect joint inflammation [30]. Here, we show that GW2580 inhibits both bone erosion and joint inflammation in multiple mouse models of RA, indicating that c-Fms plays a critical role in regulating inflammatory arthritis. Reported disparities in the effects of candidate therapeutic compounds on inflammatory arthritis may be due to differences in the RA models used, none of which encompasses all of the features of RA; therefore, candidate therapeutics should ideally be tested in multiple models of RA [35]. We investigated the effects of GW2580 in three distinct models of RA. Induction of arthritis in the CIA model is dependent on adaptive immune responses, whereas induction in the CAIA and $\mathrm{K} / \mathrm{BxN}$ models-antibody transfer models that bypass the requirement for $\mathrm{T}$ and $B$ cells-is dependent solely on innate immune responses. Inhibition of c-Fms reduced arthritis severity in both types of RA models, indicating that c-Fms is integral to the pathogenesis of autoimmune arthritis. Furthermore, GW2580 reduced arthritis severity when administered either before the onset of arthritis or following the establishment of arthritis, suggesting that c-Fms plays a role in both the early and the chronic stages of autoimmune arthritis. Our data are consistent with previous findings demonstrating the importance of the c-Fms ligand M-CSF in CIA: exogenous M-CSF was shown to exacerbate CIA, whereas a neutralizing antibody against $M$-CSF reduced arthritis severity and M-CSF deficiency conferred resistance to CIA [36]. Recently, IL-34 was identified as a second ligand for c-Fms [22]; the role of IL-34-mediated stimulation of c-Fms in RA remains to be investigated.

M-CSF/c-Fms signaling drives the differentiation of monocytes into macrophages or osteoclasts, both of which contribute to synovial inflammation and joint destruction in RA. Using mouse models of autoimmune arthritis, we demonstrate that GW2580 blocks the formation of macrophages and osteoclasts in vitro and reduces macrophage infiltration of joints in vivo. Furthermore, we demonstrate that M-CSF and both total and activated c-Fms are highly expressed in the synovium of RA patients. Together, our data underscore the importance of the M-CSF/c-Fms signaling pathway in RA pathogenesis and suggest that inhibition of c-Fms ameliorates autoimmune arthritis by abrogating the differentiation of monocyte lineage cells.

An increase in osteoclast numbers in RA leads to pathogenic degradation of bone [37]. Both the M-CSF/ c-Fms and the RANKL/RANK signaling pathways are required for formation of osteoclasts. Results from a recent phase II trial demonstrated that blockade of RANKL with denosumab decreased structural damage, including bone erosions, in patients with RA; however, it had no effect on the American College of Rheumatology response criteria, DAS28 (disease activity score using 28 joint counts) criteria, or RA flares [38]. Similarly, preclinical studies demonstrated that RANKL inhibition mitigated bone erosions without improving clinical parameters of disease in autoimmune arthritis [39]. Thus, in the treatment of autoimmune arthritis, inhibiting RANKL is not as efficacious as inhibiting cFms. We propose that inhibition of c-Fms is more efficacious because c-Fms is crucial to the formation of macrophages in addition to osteoclasts.

The clinical improvement following c-Fms inhibition in our autoimmune arthritis models was rapid. Such rapidity of the response cannot be attributed to effects on differentiation of monocyte lineage cells, a process that occurs over several days, nor can it be attributed to effects on T cells as splenocytes from GW2580-treated CIA mice exhibited activity similar to splenocytes from vehicle-treated CIA mice. This is in contrast to results from studies using the c-Fms inhibitor Ki20227, in which Ki20227-mediated suppression of CIA was associated with a reduction in splenocyte activity [40]. 
However, Ki20227 inhibits vascular endothelial growth factor receptor-II (VEGFR-II) in addition to c-Fms, and its selectivity has not been extensively evaluated [41]; it is possible that Ki20227 inhibits additional kinases that are important in T-cell signaling. What then is the basis for such a rapid response to c-Fms inhibition? A crucial role for macrophages in the development of RA is the production of TNF and other cytokines that promote inflammation $[1,42]$. We demonstrate that $\mathrm{c}-\mathrm{Fms}$ activation primes macrophage TNF production such that macrophages produce much greater amounts of TNF upon Fc receptor stimulation, an important trigger of synovitis in RA [34]. Thus, we propose that blockade of a c-Fmsmediated priming effect on macrophage TNF production underlies the rapidity of the clinical response to c-Fms inhibition.

The CAIA and $\mathrm{K} / \mathrm{BxN}$ models result in the formation of immune complexes that activate complement, resulting in the recruitment and activation of neutrophils and macrophages to produce TNF and other inflammatory mediators. As shown in Figure 5b, we demonstrate that specific Fms inhibition potently blocks TNF release in response to immune complexes. Thus, inhibition of TNF production from immune complex-stimulated macrophages by GW2580 likely represents a primary mechanism by which Fms inhibition provides benefit in CAIA and $\mathrm{K} / \mathrm{BxN}$ arthritis.

Although our results indicate that c-Fms plays a key role in the pathogenesis of RA, they do not preclude contributions by other receptor tyrosine kinases. Mice in which c-Kit signaling is impaired-owing to a lossof-function mutation in either the gene encoding c-Kit or the gene encoding the $\mathrm{c}$-Kit ligand-are resistant to antibody-mediated arthritis [43,44]. Indeed, masitinib, a tyrosine kinase inhibitor that is more selective than imatinib for c-Kit, recently demonstrated favorable trends in an uncontrolled phase II trial [45]. However, masitinib potently inhibits the PDGFR $\alpha / \beta$ and Lyn kinases in addition to c-Kit, and thus the feasibility of treating RA by selectively inhibiting c-Kit remains to be explored. Furthermore, PDGFR signaling in FLSs and other cell types may also contribute to the development of autoimmune arthritis. Hyperproliferation of FLSs, which contribute to the formation of tumor-like pannus in RA joints, likely results in part from an increase in PDGFR expression and activity [46]. In addition, PDGFR signaling may promote synovitis in RA by inducing the production of proinflammatory cytokines by FLSs [47]. To date, however, assessment of the importance of PDGFR in autoimmune arthritis and RA has been hampered by the lethality of PDGFR or PDGFR $\beta$ deficiency in mice and the lack of smallmolecule inhibitors that selectively target PDGFR $\alpha / \beta$.
Thus, the role of PDGFR in autoimmune arthritis awaits further clarification.

\section{Conclusions}

We show that c-Fms plays a pivotal role in autoimmune arthritis by promoting the differentiation and priming of monocyte lineage cells. Selective c-Fms inhibition affords targeting of multiple pathogenic cell types and responses in autoimmune arthritis and represents a promising approach to the treatment of RA. Clinical trials are warranted to evaluate the efficacy and therapeutic index of c-Fms inhibitors in RA.

\footnotetext{
Additional file 1: GW2580 potently inhibits c-Fms kinase and does not cross-react with other imatinib-targeted kinases at clinically relevant concentrations. (a, b) Cell-free kinase activity assay with time-resolved fluorescent readout for determination of the $\mathrm{IC}_{50}$ of imatinib and GW2580 for the kinases (a) Abl and (b) c-Kit. (c) Cell-based assay for determination of the $\mathrm{IC}_{50}$ of imatinib and GW2580 for c-Fms. Human peripheral blood mononuclear cells were treated with M-CSF in the presence of 0-10 $\mathrm{MM}$ GW2580 or imatinib for 48 hours. Macrophages were counted and values expressed relative to M-CSF treatment alone. (d) Cell-based assay for determination of the $\mathrm{IC}_{50}$ of imatinib and GW2580 for PDGFR. Fibroblast-like synoviocytes from a human RA patient were incubated with PDGF-bb in the presence of 0-30 $\mu \mathrm{M}$ GW2580 or imatinib. After 48 hours, FLS cultures were pulsed with [ $\left.{ }^{3} \mathrm{H}\right]$ thymidine for 18 hours. Values are expressed relative to PDGF-bb treatment. Data shown in $\mathbf{a}-\mathbf{d}$ are representative of at least 2 independent experiments.

Additional file 2: GW2580 does not modulate T-cell function in vivo. Splenocytes were harvested from DBA/1 mice with $\mathrm{CIA}$ and treated with GW2580, imatinib, or vehicle, and stimulated with $20 \mu \mathrm{g} / \mathrm{ml}$ heatdenatured, whole $\mathrm{Cll}$. $\left[{ }^{3} \mathrm{H}\right]$ thymidine incorporation was used to measure proliferation of Cll-specific T cells. IFN $\gamma$, TNF $\alpha$ and IL-10 were measured in culture supernatants by ELISA. Values are the mean \pm SEM. ${ }^{*} P<0.05$ compared with stimulated cells from vehicle-treated CIA mice. Results are representative of 2 independent experiments.
}

\section{Abbreviations}

CAIA: anti-collagen antibody-induced arthritis; CFA: complete Freund's adjuvant; CIA: collagen-induced arthritis; Cll: collagen type II; ELISA: enzymelinked immunosorbent assay; FLS: fibroblast-like synoviocyte; $I C_{50}$ : half inhibitory concentration; IFA: incomplete Freund's adjuvant; IL: interleukin; i. p.: intraperitoneal; LPS: lipopolysaccharide; M-CSF: macrophage colonystimulating factor; OA: osteoarthritis; PDGFR: platelet-derived growth factor receptor; PSA: psoriatic arthritis; RA: rheumatoid arthritis; RANKL: receptor activator of nuclear factor-kappa-B ligand; TNF: tumor necrosis factor; TRAP ${ }^{+}$: tartrate-resistant acid phosphatase-positive.

\section{Acknowledgements}

This work was supported by National Institutes of Health $(\mathrm{NIH})$ National Heart Lung and Blood Institute contract N01 HV 28183, NIH National Institute of Arthritis and Musculoskeletal and Skin Diseases R01 AR-054822, and Veterans Affairs Health Care System funding awarded to WHR as well as an NIH F31 Fellowship Award and Stanford University Lieberman Fellowship Award granted to RTP. We thank Darren R Veach (Memorial Sloan-Kettering Cancer Center) for chemically synthesized imatinib, Jessica Hamerman (Benaroya Research Institute, Seattle, WA, USA) for insights on Fc receptor activation, and members of the WHR laboratory for fruitful discussions. We appreciate GlaxoSmithKline's provision of GW2580 for the arthritis prevention studies. 


\section{Author details}

'Department of Medicine, Division of Immunology and Rheumatology, Stanford University School of Medicine, CCSR 4135, 269 Campus Drive, Stanford, CA 94305, USA. ${ }^{2}$ GRECC, Palo Alto VA Health Care System, 3801 Miranda Avenue, Palo Alto, CA 94304, USA. ${ }^{3}$ Department of Neurology and Neurological Sciences, Stanford University School of Medicine, Beckman B002, 279 Campus Drive, Stanford, CA 94305, USA. ${ }^{4}$ Department of Medicine, Division of Rheumatology, Immunology and Allergy, Brigham and Women's Hospital, Harvard Medical School, 1 Jimmy Fund Way, Smith 552B, Boston, MA 02115, USA.

\section{Authors' contributions}

RTP helped to design the experiments and interpret the data, contributed to the writing of the manuscript, and helped to perform the experiments and generate the datasets. WHR helped to design the experiments and interpret the data and contributed to the writing of the manuscript. AC, MM, EAS, QW, OS, CR, and PPH helped to perform the experiments and generate the datasets. TML contributed to the interpretation of the datasets and the writing of the manuscript. DML oversaw the immunohistochemistry studies along with presentation and interpretation of the immunohistochemistry data. All authors read and approved the final manuscript.

\section{Competing interests}

The authors declare that they have no competing interests.

Received: 12 October 2009 Revisions requested: 30 November 2009 Revised: 25 December 2009 Accepted: 24 February 2010 Published: 24 February 2010

\section{References}

1. Firestein GS: Evolving concepts of rheumatoid arthritis. Nature 2003, 423:356-361.

2. Weinblatt ME, Kremer JM, Bankhurst AD, Bulpitt KJ, Fleischmann RM, Fox RI, Jackson CG, Lange $M$, Burge DJ: A trial of etanercept, a recombinant tumor necrosis factor receptor:Fc fusion protein, in patients with rheumatoid arthritis receiving methotrexate. N Engl J Med 1999, 340:253-259.

3. Edwards JC, Szczepanski L, Szechinski J, Filipowicz-Sosnowska A, Emery P, Close DR, Stevens RM, Shaw T: Efficacy of B-cell-targeted therapy with rituximab in patients with rheumatoid arthritis. N Engl J Med 2004, 350:2572-2581.

4. Genovese MC, Becker JC, Schiff M, Luggen M, Sherrer Y, Kremer J, Birbara C, Box J, Natarajan K, Nuamah I, Li T, Aranda R, Hagerty DT, Dougados M: Abatacept for rheumatoid arthritis refractory to tumor necrosis factor alpha inhibition. N Engl J Med 2005, 353:1114-1123.

5. Druker BJ, Talpaz M, Resta DJ, Peng B, Buchdunger E, Ford JM, Lydon NB, Kantarjian H, Capdeville R, Ohno-Jones S, Sawyers CL: Efficacy and safety of a specific inhibitor of the BCR-ABL tyrosine kinase in chronic myeloid leukemia. N Engl J Med 2001, 344:1031-1037.

6. Demetri $G D$, von Mehren $M$, Blanke $C D$, Abbeele Van den $A D$, Eisenberg $B$, Roberts PJ, Heinrich MC, Tuveson DA, Singer $S$, Janicek M, Fletcher JA, Silverman SG, Silberman SL, Capdeville R, Kiese B, Peng B, Dimitrijevic S, Druker BJ, Corless C, Fletcher CD, Joensuu H: Efficacy and safety of imatinib mesylate in advanced gastrointestinal stromal tumors. $N$ Engl $J$ Med 2002, 347:472-480

7. Ames PR, Aye WW, Beatty C, O'Reilly D: Imatinib treatment of seropositive arthritis in a young woman with chronic myeloid leukemia. J Rheumatol 2008, 35:1682.

8. Miyachi K, Ihara A, Hankins RW, Murai R, Maehiro S, Miyashita H: Efficacy of imatinib mesylate (STI571) treatment for a patient with rheumatoid arthritis developing chronic myelogenous leukemia. Clin Rheumatol 2003, 22:329-332.

9. Eklund KK, Joensuu $\mathrm{H}$ : Treatment of rheumatoid arthritis with imatinib mesylate: clinical improvement in three refractory cases. Ann Med 2003, 35:362-367.

10. Koyama K, Hatsushika K, Ando T, Sakuma M, Wako M, Kato R, Haro H Sugiyama H, Hamada Y, Ogawa H, Nakao A: Imatinib mesylate both prevents and treats the arthritis induced by type II collagen antibody in mice. Mod Rheumatol 2007, 17:306-310.

11. Ando W, Hashimoto J, Nampei A, Tsuboi H, Tateishi K, Ono T, Nakamura N, Ochi T, Yoshikawa H: Imatinib mesylate inhibits osteoclastogenesis and joint destruction in rats with collagen-induced arthritis (CIA). J Bone Miner Metab 2006, 24:274-282.

12. Paniagua RT, Sharpe O, Ho PP, Chan SM, Chang A, Higgins JP, Tomooka BH, Thomas FM, Song JJ, Goodman SB, Lee DM, Genovese MC, Utz PJ, Steinman L, Robinson WH: Selective tyrosine kinase inhibition by imatinib mesylate for the treatment of autoimmune arthritis. J Clin Invest 2006, 116:2633-2642.

13. Buchdunger $E$, Matter A, Druker BJ: Bcr-Abl inhibition as a modality of CML therapeutics. Biochim Biophys Acta 2001, 1551:M11-18.

14. Dewar AL, Cambareri AC, Zannettino AC, Miller BL, Doherty KV, Hughes TP, Lyons $\mathrm{AB}$ : Macrophage colony-stimulating factor receptor $\mathrm{c}-\mathrm{fms}$ is a novel target of imatinib. Blood 2005, 105:3127-3132.

15. Fabian MA, Biggs WH, Treiber DK, Atteridge CE, Azimioara MD, Benedetti MG, Carter TA, Ciceri P, Edeen PT, Floyd M, Ford JM, Galvin M, Gerlach JL, Grotzfeld RM, Herrgard S, Insko DE, Insko MA, Lai AG, Lelias JM, Mehta SA, Milanov ZV, Velasco AM, Wodicka LM, Patel HK, Zarrinkar PP, Lockhart DJ: A small molecule-kinase interaction map for clinical kinase inhibitors. Nat Biotechnol 2005, 23:329-336.

16. Serbina NV, Jia T, Hohl TM, Pamer EG: Monocyte-mediated defense against microbial pathogens. Annu Rev Immunol 2008, 26:421-452.

17. Pixley FJ, Stanley ER: CSF-1 regulation of the wandering macrophage: complexity in action. Trends Cell Biol 2004, 14:628-638.

18. Boyle WJ, Simonet WS, Lacey DL: Osteoclast differentiation and activation. Nature 2003, 423:337-342.

19. Yao Z, Li P, Zhang Q, Schwarz EM, Keng P, Arbini A, Boyce BF, Xing L: Tumor necrosis factor-alpha increases circulating osteoclast precursor numbers by promoting their proliferation and differentiation in the bone marrow through up-regulation of c-Fms expression. $J$ Biol Chem 2006, 281:11846-11855.

20. Yang PT, Kasai $H$, Xiao WG, Zhao LJ, He LM, Yamashita A, Deng XW, Ito M: Increased expression of macrophage colony-stimulating factor in ankylosing spondylitis and rheumatoid arthritis. Ann Rheum Dis 2006, 65:1671-1672.

21. Nakano K, Okada Y, Saito K, Tanikawa R, Sawamukai N, Sasaguri Y, Kohro T, Wada Y, Kodama T, Tanaka Y: Rheumatoid synovial endothelial cells produce macrophage colony-stimulating factor leading to osteoclastogenesis in rheumatoid arthritis. Rheumatology (Oxford) 2007, 46:597-603.

22. Lin $H$, Lee $E$, Hestir $K$, Leo C, Huang M, Bosch E, Halenbeck R, Wu G, Zhou A, Behrens D, Hollenbaugh D, Linnemann T, Qin M, Wong J, Chu K, Doberstein SK, Williams LT: Discovery of a cytokine and its receptor by functional screening of the extracellular proteome. Science 2008, 320:807-811.

23. Rosloniec EF, Kang AH, Myers LK, Cremer MA: Collagen-induced arthritis. Current Protocols in Immunology Hoboken, NJ: John Wiley and Sons, IncCoico R, Shevach E 1994, 1515.11-15.15.24.

24. Deng GM, Zheng L, Chan FK, Lenardo M: Amelioration of inflammatory arthritis by targeting the pre-ligand assembly domain of tumor necrosis factor receptors. Nat Med 2005, 11:1066-1072.

25. Shin K, Gurish MF, Friend DS, Pemberton AD, Thornton EM, Miller HR, Lee DM: Lymphocyte-independent connective tissue mast cells populate murine synovium. Arthritis Rheum 2006, 54:2863-2871.

26. Shin K, Nigrovic PA, Crish J, Boilard E, McNeil HP, Larabee KS, Adachi R, Gurish MF, Gobezie R, Stevens RL, Lee DM: Mast cells contribute to autoimmune inflammatory arthritis via their tryptase/heparin complexes. $\mathrm{J}$ Immunol 2009, 182:647-656.

27. Stanley ER: Murine bone marrow-derived macrophages. Methods Mol Biol 1997, 75:301-304

28. Hamerman JA, Tchao NK, Lowell CA, Lanier LL: Enhanced Toll-like receptor responses in the absence of signaling adaptor DAP12. Nat Immunol 2005, 6:579-586.

29. Conway JG, McDonald B, Parham J, Keith B, Rusnak DW, Shaw E, Jansen M, Lin P, Payne A, Crosby RM, Johnson JH, Frick L, Lin MH, Depee S, Tadepalli S, Votta B, James I, Fuller K, Chambers TJ, Kull FC, Chamberlain SD, Hutchins JT: Inhibition of colony-stimulating-factor-1 signaling in vivo with the orally bioavailable cFMS kinase inhibitor GW2580. Proc Nat Acad Sci USA 2005, 102:16078-16083.

30. Conway JG, Pink H, Bergquist ML, Han B, Depee S, Tadepalli S, Lin P, Crumrine RC, Binz J, Clark RL, Selph JL, Stimpson SA, Hutchins JT, Chamberlain SD, Brodie TA: Effects of the cFMS kinase inhibitor 5-(3methoxy-4-((4-methoxybenzyl)oxy)benzyl)pyrimidine-2,4-diamine 
(GW2580) in normal and arthritic rats. J Pharmacol Exp Ther 2008, 326:41-50.

31. Gredmark S, Britt WB, Xie X, Lindbom L, Soderberg-Naucler C: Human cytomegalovirus induces inhibition of macrophage differentiation by binding to human aminopeptidase N/CD13. J Immunol 2004, 173:4897-4907.

32. Irvine KM, Burns CJ, Wilks AF, Su S, Hume DA, Sweet MJ: A CSF-1 receptor kinase inhibitor targets effector functions and inhibits pro-inflammatory cytokine production from murine macrophage populations. FASEB $J$ 2006, 20:1921-1923.

33. Xu W, Schlagwein N, Roos A, Berg van den TK, Daha MR, van Kooten C: Human peritoneal macrophages show functional characteristics of $M$ CSF-driven anti-inflammatory type 2 macrophages. Eur J Immunol 2007, 37:1594-1599.

34. Monach PA, Hueber W, Kessler B, Tomooka BH, Benbarak M, Simmons BP, Wright J, Thornhill TS, Monestier M, Ploegh H, Robinson WH, Mathis D, Benoist C: A broad screen for targets of immune complexes decorating arthritic joints highlights deposition of nucleosomes in rheumatoid arthritis. Proc Natl Acad Sci USA 2009, 106:15867-15872.

35. Firestein GS: Rheumatoid arthritis in a mouse? Nat Clin Pract Rheumatol 2009, 5:1.

36. Campbell IK, Rich MJ, Bischof RJ, Hamilton JA: The colony-stimulating factors and collagen-induced arthritis: exacerbation of disease by M-CSF and G-CSF and requirement for endogenous M-CSF. J Leukoc Biol 2000, 68:144-150.

37. Kim KW, Cho ML, Lee SH, Oh HJ, Kang CM, Ju JH, Min SY, Cho YG, Park SH, Kim HY: Human rheumatoid synovial fibroblasts promote osteoclastogenic activity by activating RANKL via TLR-2 and TLR-4 activation. Immunol Lett 2007, 110:54-64.

38. Cohen SB, Dore RK, Lane NE, Ory PA, Peterfy CG, Sharp JT, Heijde van der $D$, Zhou L, Tsuji W, Newmark R: Denosumab treatment effects on structural damage, bone mineral density, and bone turnover in rheumatoid arthritis: a twelve-month, multicenter, randomized, doubleblind, placebo-controlled, phase II clinical trial. Arthritis Rheum 2008, 58:1299-1309.

39. Kong YY, Feige U, Sarosi I, Bolon B, Tafuri A, Morony S, Capparelli C, Li J, Elliott R, McCabe S, Wong T, Campagnuolo G, Moran E, Bogoch ER, Van G, Nguyen LT, Ohashi PS, Lacey DL, Fish E, Boyle WJ, Penninger JM: Activated $\mathrm{T}$ cells regulate bone loss and joint destruction in adjuvant arthritis through osteoprotegerin ligand. Nature 1999, 402:304-309.

40. Ohno H, Uemura Y, Murooka H, Takanashi H, Tokieda T, Ohzeki Y, Kubo K, Serizawa I: The orally-active and selective c-Fms tyrosine kinase inhibitor Ki20227 inhibits disease progression in a collagen-induced arthritis mouse model. Eur J Immunol 2008, 38:283-291.

41. Ohno H, Kubo K, Murooka H, Kobayashi Y, Nishitoba T, Shibuya M, Yoneda T, Isoe T: A c-fms tyrosine kinase inhibitor, Ki20227, suppresses osteoclast differentiation and osteolytic bone destruction in a bone metastasis model. Mol Cancer Ther 2006, 5:2634-2643.

42. Choy EH, Panayi GS: Cytokine pathways and joint inflammation in rheumatoid arthritis. N Engl J Med 2001, 344:907-916.

43. Lee DM, Friend DS, Gurish MF, Benoist C, Mathis D, Brenner MB: Mast cells: a cellular link between autoantibodies and inflammatory arthritis. Science 2002, 297:1689-1692.

44. Zhou JS, Xing W, Friend DS, Austen KF, Katz HR: Mast cell deficiency in Kit (W-sh) mice does not impair antibody-mediated arthritis. J Exp Med 2007, 204:2797-2802.

45. Tebib J, Mariette X, Bourgeois P, Flipo RM, Gaudin P, Le Loet $X$, Gineste $P$, Guy L, Mansfield CD, Moussy A, Dubreuil P, Hermine O, Sibilia J: Masitinib in the treatment of active rheumatoid arthritis: results of a multicentre, open-label, dose-ranging, phase 2a study. Arthritis Res Ther 2009, 11:R95.

46. Watanabe N, Ando K, Yoshida S, Inuzuka S, Kobayashi M, Matsui N, Okamoto T: Gene expression profile analysis of rheumatoid synovial fibroblast cultures revealing the overexpression of genes responsible for tumor-like growth of rheumatoid synovium. Biochem Biophys Res Commun 2002, 294:1121-1129.

47. Cheon H, Sun YK, Yu SJ, Lee YH, Ji JD, Song GG, Lee JH, Kim MK, Sohn J: Platelet-derived growth factor-AA increases IL-1 beta and IL-8 expression and activates NF-kappaB in rheumatoid fibroblast-like synoviocytes. Scand J Immunol 2004, 60:455-462.

\section{doi:10.1186/ar2940}

Cite this article as: Paniagua et al:: c-Fms-mediated differentiation and priming of monocyte lineage cells play a central role in autoimmune arthritis. Arthritis Research \& Therapy 2010 12:R32.

\section{Submit your next manuscript to BioMed Central and take full advantage of:}

- Convenient online submission

- Thorough peer review

- No space constraints or color figure charges

- Immediate publication on acceptance

- Inclusion in PubMed, CAS, Scopus and Google Scholar

- Research which is freely available for redistribution 